\title{
Lint Quality as Influenced by of Time of Planting in Bt cotton (Gossypium hirsutum L.) Cultivars in TBP Irrigation Command
}

\author{
Vinayak Hosamani $^{1^{*}}$, B.M. Chittapur ${ }^{2}$, Mallikarjun $^{3}$, A.S. Halepyati ${ }^{4}$, \\ Satyanarayana Rao ${ }^{5}$, M.B. Patil ${ }^{6}$, N.L. Rajesh ${ }^{7}$ and Venkatesh Hosamani ${ }^{8}$
}

${ }^{I}$ P2 BSF, Nagenahally, Kunigal, Central Silk Board, Bangalore/ UAS, Raichur, Karnataka, India

${ }^{2}$ Directorate of Extension, University of Agricultural Sciences, Raichur, Karnataka, India

${ }^{3} e-S A P$, Project, University of Agricultural Sciences, Raichur, Karnataka, India

${ }^{4}$ University of Agricultural Sciences, Raichur, Karnataka, India

${ }^{5}$ Research Institute on Organic Farming, MARS. UAS, Raichur, Karnataka, India

\author{
${ }^{6}$ AEEC, Koppal, UAS, Raichur, Karnataka, India \\ ${ }^{7}(S S \& A C), C O A, U A S$, Raichur, Karnataka, India \\ ${ }^{8}$ Entomology, COH, Munirabad-Koppal, Karnataka, India \\ *Corresponding author
}

\section{A B S T R A C T}

\section{Keywords}

Bt cotton, Date of sowing, Quality

Article Info

Accepted:

22 July 2018

Available Online:

10 August 2018
Field experiments were conducted at College of Agriculture Farm, Raichur during kharif 2014-15 and 2015-16 to study the interaction between commercial Bt cultivars (Bindas, Bunny, ATM and Dr. Brent) and planting time (II fortnight of June, and I and II fortnights of July and August) on crop performance. Results revealed significantly higher fibre finess (37.1) fibre length $(\mathrm{mm})$ (37.1), Uniformity ratio $(\%)(50.06 \%)$, lint index $(8.65)$, seed index $(10.49 \mathrm{~g})$, maturity ratio $(0.86)$, bundle strength $\left(30.0 \mathrm{~g} \mathrm{tex}^{-1}\right)$ and ginning percentage (38.9) on pooled basis recorded with early sowing in June particularly with cv. Bindas compared to delayed sowings with same or different cultivars.

\section{Introduction}

Cotton (Gossypium spp.), 'the king of fibers' also popularly known as 'the white gold' enjoys a pre-eminent position amongst cash crops in the world and in India as well. It is the nature's most precious gift to the mankind, contributed by the genus Gossypium to clothe the people all over the world. Four out of the 50 recognized Gossypium species in the world viz., G. arboreum, G. herbaceum, G. hirsutum and $G$. barbadense are cultivated for natural fibre, and India is the only country in the world where all the four species and some of their hybrid derivatives are commercially grown. In fact, the Indian sub-continent has a long history of cultivating traditional varieties and hybrids of cotton. Productivity of cotton can be considerably improved by cultivation of $B t$ cotton hybrids with suitable sowing time. 
Time of sowing affects plant growth and fruiting through its effects on the microclimate of the crop. Lint yield is a product of number of mature bolls produced/unit area. Late sowing resulted in decrease in opened bolls, increased pest attack and reduction in yield. Early sowing of the crop helped in the timely sowing of the succeeding rabi crops. Planting time differs from place to place for obtaining higher yields. In Haryana, sowing is recommended in the month of April to midMay. The $B t$ cotton hybrids are comparatively fast growing and gave better yields even under late sown conditions. However, little research work has been carried out under Haryana conditions, on suitability of $B t$ cotton hybrids under different sowing dates. Keeping the above aspects, the present investigation was planned to study the performance of different $B t$ cotton hybrids (Gossypium hirsutum L.) under varying dates of sowing. Proper sowing time plays pivotal role in yield potential; similarly, proper nitrogen dose is essential for optimum growth and yield. To examine the productivity of four cotton cultivars under two different sowing dates. To evaluate the differences in the yield and yield components of different cotton cultivars with different sowing dates

\section{Materials and Methods}

Investigations were carried out at Agricultural College Farm, University of Agricultural Sciences, Raichur, Karnataka falling under Tunga Bhadra Project irrigation command under deep black soil under irrigation. The experiment was laid out using Split plot design consisting of five main plot treatments (sowing date: D1- Second fortnight of June, D2- First fortnight of July, D3- Second fortnight of July, D4- First fortnight of August, and D5- Second fortnight of August) and four sub plot treatments (cotton cultivars: G1- Bindas, G2- Bunny-Bt, G3- ATM and G4- Dr. Brent) with three replications. The recommended dose of fertilizers 150: $75: 75 \mathrm{~kg}$ ha $^{-1} \mathrm{~N}, \mathrm{P}_{2} \mathrm{O}_{5}$ and $\mathrm{K}_{2} \mathrm{O}$ were applied during both the years. Important growth and yield parameters were monitored and the data were subjected to statistical analysis (Gomez and Gomez, 1984). The means were compared using Duncan's Multiple Range Test (DMRT) using SPSS 16.0 version at $\mathrm{P}=0.05$

\section{Results and Discussion}

Fibre fineness was significantly influenced due to sowing dates, cultivars and their interactions during both the years and on pooled basis (Table 1-4). Early sowing during II fortnight of June $\left(\mathrm{D}_{1}\right)$ consistently recorded significantly higher fineness (4.79 on pooled basis) among all and the values decreased steadily with delay in sowing wherein the last sowing during II fortnight of August $\left(\mathrm{D}_{5}\right)$ recorded significantly lower fineness (3.92 on pooled basis) while others had intermediary values. Variations among cultivars were significant during second year and in pooled mean. $\mathrm{Cv}$. Bindas $\left(\mathrm{G}_{1}\right)$ recorded significantly higher fineness (4.47) among all, while other cultivars were at par and differed significantly from the former $\left(G_{1}\right)$. Fibre fineness was higher with early sowing irrespective of cultivars used and it slowly decreased with delay in sowing up to August end. Among all treatment combination $\mathrm{cv}$ Bindas sown during II fortnight of June $\left(D_{1} G_{1}\right)$ (4.87 on pooled basis) was superior in fibre fineness while cvs. Dr Brent and ATM sown during II fortnight of August $\left(\mathrm{D}_{5} \mathrm{G}_{4}\right.$ and $\left.\mathrm{D}_{5} \mathrm{G}_{3}\right)$ recorded significantly lower fibre fineness (3.81 and 3.84 , respectively on pooled basis).

Fibre length differed significantly due to different sowing dates, cultivars and their interactions (Table 1-4). Among different dates of sowing, significantly higher fibre length (36.9 on pooled basis) was recorded with second fortnight of June $\left(\mathrm{D}_{1}\right)$ during both the years and on the pooled basis. Fibre length 
$(\mathrm{mm})$ decreased with the delayed sowing times and recorded the lowest length (27.7 on pooled basis) with the last sowing during II fortnight of August ( $\left.D_{5}\right)$. Effect of genotypes revealed significant variation only during second year wherein $\mathrm{cv}$. Bindas $\left(\mathrm{V}_{1}\right)$ fared superior (33.4) while cv. Bunny Bt $\left(\mathrm{V}_{2}\right)$ had lower fibre length among all. Fibre length was higher with early sowing irrespective of cultivars used and it slowly decreased with delay in sowing up to August end. Among all the treatment combinations cv. Bindas sown during II fortnight of June $\left(\mathrm{D}_{1} \mathrm{G}_{1}\right)$ (37.1 on pooled basis) was superior in fibre length and crop sown during I fortnight of July was on par irrespective of cultivars used, while cvs. Bunny Bt, Dr Brent and ATM sown during II fortnight of August $\left(\mathrm{D}_{5} \mathrm{G}_{2-4}\right)$ recorded significantly lower fibre length (27.1 to 27.5 on pooled basis). Other treatment combinations had intermediary values.

The data on uniformity ratio revealed significant differences due to sowing dates, cultivars and their interactions (Table 1-4). Among the different dates of sowing, significantly higher uniformity ratio (49.8 on pooled basis) was recorded with earliest sowing during II fortnight of June $\left(\mathrm{D}_{1}\right)$ during both the years and on the pooled basis. Uniformity ratio decreased with the delay in sowing and recorded lower value (45.8 on pooled basis) with last sowing during II fortnight of August $\left(D_{5}\right)$, while $\mathrm{D}_{4}$ was on par.

Effect of genotypes revealed significant variation only during second year and on pooled basis wherein cv. Bindas $\left(\mathrm{G}_{1}\right)$ fared superior (47.7 on pooled basis) while others were on par with one another and stood second. Again uniformity ratio was higher with early sowing irrespective of cultivars used and it slowly decreased with delay in sowing up to August end among treatment combinations. Among all, cv. Bindas sown during II fortnight of June $\left(D_{1} G_{1}\right)$ (50.6 on pooled basis) was superior in uniformity ratio and crop sown during I fortnight of July was on par irrespective of cultivars used except cv. Dr Brent. Whereas, cvs. Bunny Bt, Dr Brent (44.8 each on pooled basis) and ATM (45.0) sown during II fortnight of August $\left(\mathrm{D}_{5} \mathrm{G}_{2-4}\right)$ recorded significantly lower uniformity ratio. Other treatment combinations had intermediary values.

Lint indices varied significantly due to sowing dates, cultivars and their interactions during both the years and on pooled basis (Table 14). Among the dates of sowing, significantly higher lint index was recorded with early sowing during II fortnight of June $\left(\mathrm{D}_{1}\right)$ (8.51 on pooled basis) followed closely by I fortnight of July $\left(D_{2}\right)$ which was on par, then on the values decreased with the delayed sowing and recorded the lowest lint index (5.29 on pooled basis) with the last sowing during II second fortnight of August $\left(D_{5}\right)$ Among the genotypes, cv. Bindas $\left(\mathrm{G}_{1}\right)$ consistently recorded higher lint index (7.64 on pooled basis) followed by cv. ATM $\left(\mathrm{G}_{3}\right)$ while cv. Bunny Bt $\left(\mathrm{G}_{2}\right)$ and Dr Brent $\left(\mathrm{G}_{4}\right)$ were on par with each other and recorded lower lint indices (7.23 and 7.24, respectively on pooled basis) among all. Among the treatment combinations, irrespective of cultivars first sowing during II fortnight of June $\left(D_{1} G_{1-4}\right)$ recorded significantly higher lint indices; cv. Bindas topping all (8.65 on pooled basis), second sowing during I fortnight of July $\left(\mathrm{D}_{2} \mathrm{G}_{1-4}\right)$ had comparable values, and then on the values decreased appreciably with considerably low values with last sowing during II fortnight of August (4.86 and 4.95, respectively with cvs. Dr Brent and Bunny Bt on pooled basis), while crop sown during I fortnight of August fared a lot better.

Sowing dates, cultivars and their interactions resulted in significant variations in seed indices during both the years and on pooled basis (Table 1-4). 
Table.1 Fibre fineness and Fibre length $(\mathrm{mm})$ of cotton as influenced by time of Planting and genotypes

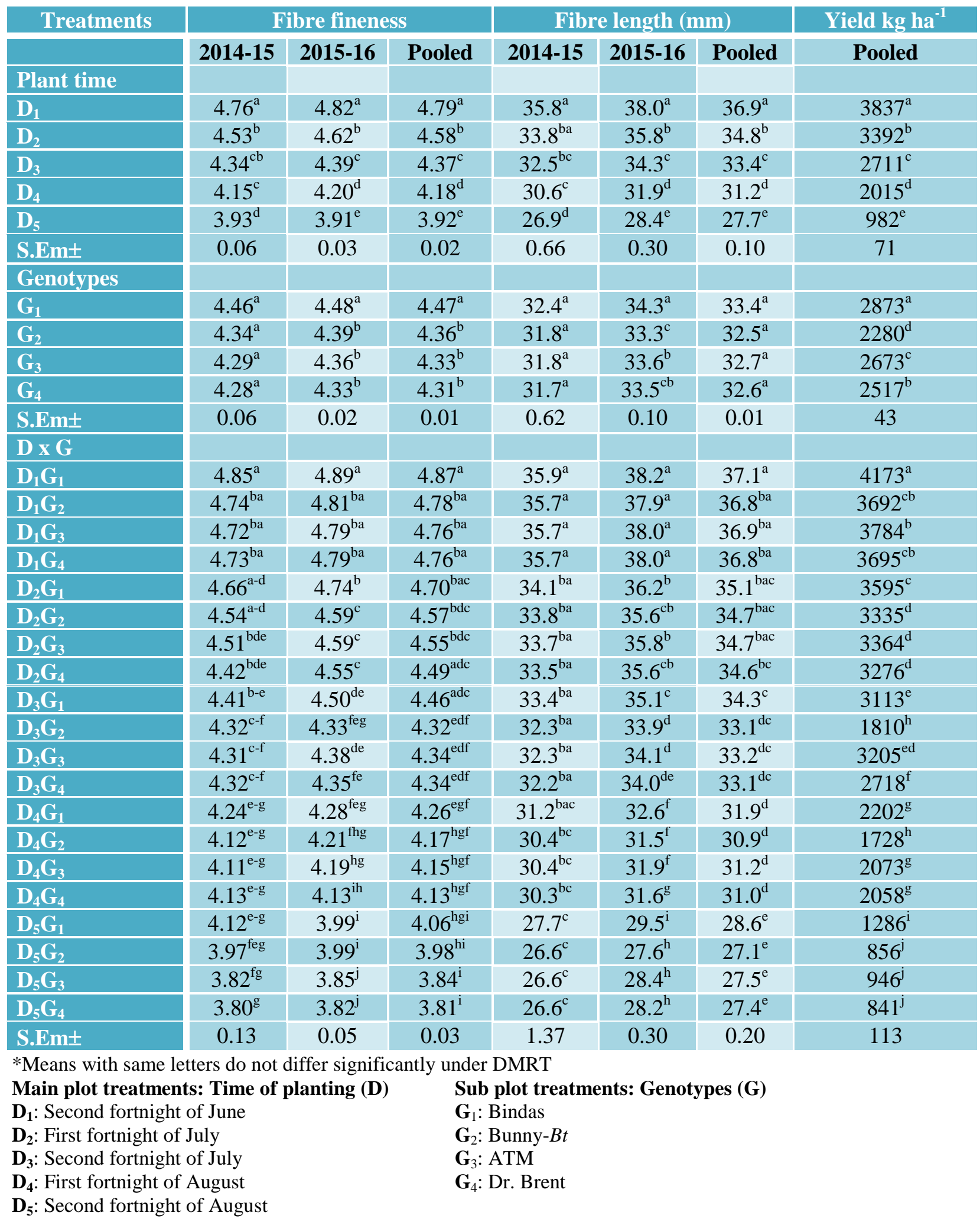


Table.2 Uniformity ratio (\%) and Lint index of cotton as influenced by time of Planting and genotypes

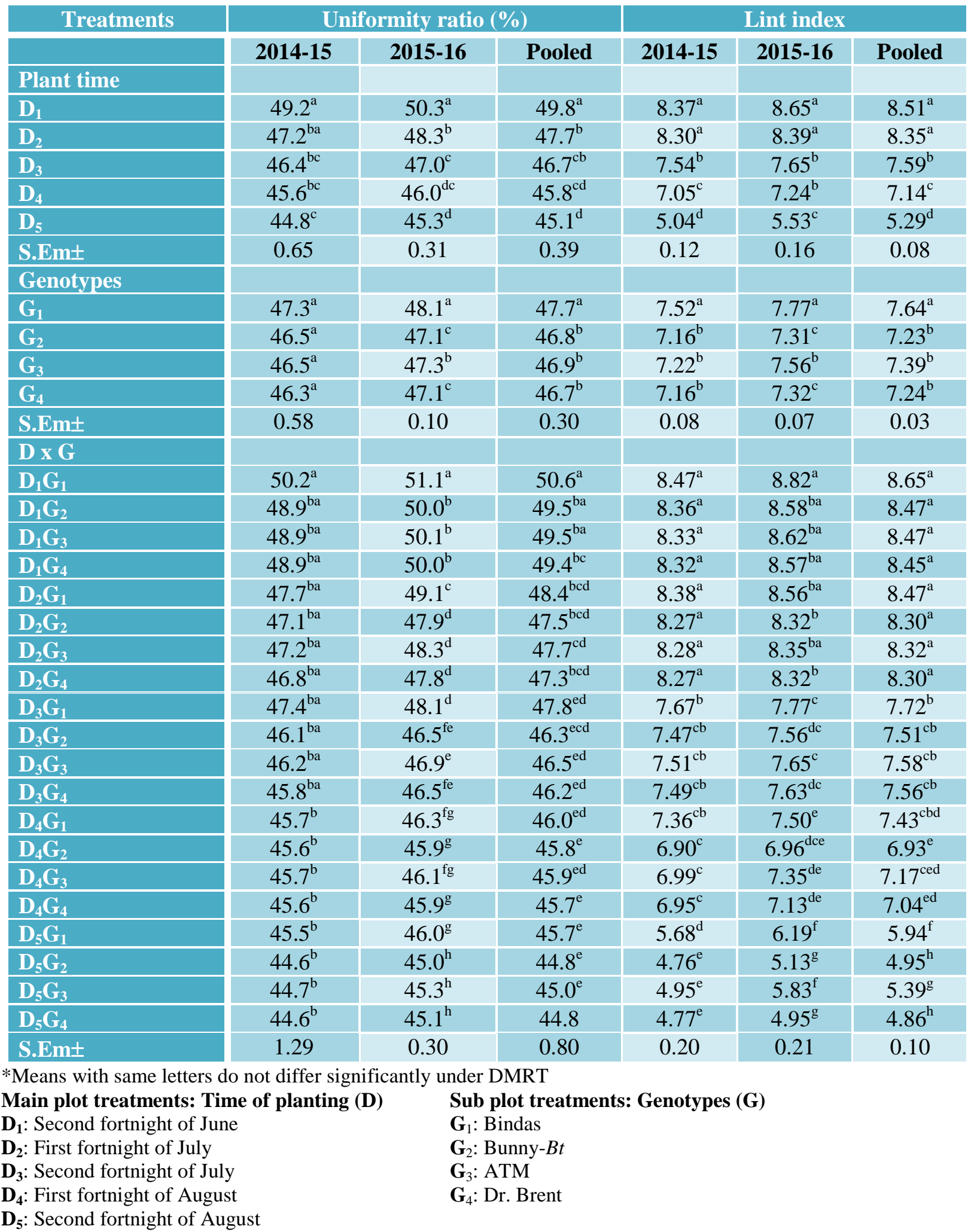


Table.3 Seed index $(\mathrm{g})$ and Maturity ratio of cotton as influenced by time of Planting and genotypes




Among the dates of sowing, significantly higher seed index (10.37 on pooled basis) was recorded with early sowing during II fortnight of June $\left(D_{1}\right)$ followed by I fortnight of July $\left(\mathrm{D}_{2}\right)$, and the values decreased with further delay in sowing and recorded the lowest seed index (8.08 on pooled basis) with the last sowing during II second fortnight of August $\left(D_{5}\right)$. Among the genotypes, cv. Bindas $\left(G_{1}\right)$ consistently recorded higher seed index (9.37 on pooled basis) followed by cvs. ATM. Bunny $B t\left(\mathrm{G}_{2}\right)$ and Dr Brent $\left(\mathrm{G}_{4}\right)$ were on par with each other and recorded next higher indices (8.31 to 9.31 on pooled basis) among all. Among the treatment combinations, irrespective of cultivars first sowing during II fortnight of June $\left(\mathrm{D}_{1} \mathrm{G}_{1-4}\right)$ recorded significantly higher seed indices; cv. Bindas and Bunny $B t$ faring well (10.49 each on pooled basis). Thereafter seed indices decreased appreciably with considerably low values with last sowing during II fortnight of August (8.03 and 8.09, respectively with cvs. Dr Brent $\left(\mathrm{D}_{5} \mathrm{G}_{4}\right)$ and Bunny $B t\left(\mathrm{D}_{5} \mathrm{G}_{2}\right)$ on pooled basis), while other combinations fared moderate values occupying middle space.

Production interventions in the form of sowing dates, cultivars and their interactions resulted in significant variations in maturity ratio during both the years and on pooled basis (Table 1-4). Among the dates of sowing, significantly higher maturity ratio was recorded consistently with early sowing during II fortnight of June $\left(\mathrm{D}_{1}\right)(0.84$ on pooled basis) followed by I fortnight of July $\left(D_{2}\right)$, and the values decreased with further delay in sowing and recorded the lowest maturity ratio ( 0.66 on pooled basis) with the last sowing during II fortnight of August $\left(D_{5}\right)$. Among the genotypes, cv. Bindas $\left(\mathrm{G}_{1}\right)$ consistently recorded higher maturity ratio ( 0.78 on pooled basis), while others fared on par with each other and stood next in the order (cvs. ATM, Bunny Bt and Dr Brent with values ranging from 0.75 to 0.76 ). Among the treatment combinations, irrespective of cultivars first sowing during II fortnight of June $\left(D_{1} G_{1-4}\right)$ recorded significantly higher maturity ratio; $\mathrm{cv}$. Bindas faring well ( 0.86 on pooled basis) and I fortnight of July ( $\left.D_{2} G_{1-4}\right)$ and cv. Bindas $\left(\mathrm{D}_{3} \mathrm{G}_{1}\right)$ sown during II fortnight of July were at par. Thereafter, maturity ratio decreased with considerably low values with the last sowing during II fortnight of August, cv, Bunny $B t\left(\mathrm{D}_{5} \mathrm{G}_{2}\right)$ recorded the lowest (0.64 on pooled basis), while other combinations fared moderate and occupied middle space.

Bundle strength differed significantly due to sowing dates, cultivars and their interactions during both years and on pooled basis (Table 1-4). Among the different dates of sowing significantly higher bundle strength (29.7 on pooled basis) was recorded with II fortnight of June $\left(D_{1}\right)$. Bundle strength decreased gradually with the delayed sowing and recorded the lowest seed index with the last sowing during II fortnight of August $\left(D_{5}\right)$ (23.1 on pooled basis). Other sowing dates occupied middle space. $\mathrm{Cv}$. Bindas $\left(\mathrm{G}_{1}\right)$ consistently recorded higher bundle strength (27.2 on pooled basis) followed by cv. ATM which was on par while cvs. Bunny $B t\left(\mathrm{G}_{2}\right)$ and Dr Brent $\left(\mathrm{G}_{4}\right)$ fared at par with comparable values (26.5 and 26.6, respectively on pooled basis) among the cultivars and stood next in the order. Among the treatment combinations, irrespective of cultivars early sowing during II fortnight of June $\left(D_{1} G_{1-4}\right)$ had significantly higher bundle strength; cv. Bindas faring better (30.0 on pooled basis), followed by those sown during I fortnight of July $\left(\mathrm{D}_{2} \mathrm{G}_{1-4}\right)$. With further delay in sowing bundle strength decreased gradually and recorded significantly lower values with last sown crop during II fortnight of August $\left(\mathrm{D}_{5} \mathrm{G}_{1-4}\right)$ where all cultivars fared on par with each other (22.8 to 23.8 on pooled basis). Other combinations had moderate values and fared in between. 
During both the years of experimentation and on pooled basis ginning percentage varied significantly due to sowing dates, cultivars and their interactions (Table 1-4). Among the different dates of sowing, significantly higher ginning percentage ( 38.5 on pooled basis) was recorded with II fortnight of June $\left(D_{1}\right)$. Ginning percentage decreased gradually with the delayed sowing and recorded the lowest ginning percentage (31.1 on pooled basis) with the last sowing during II fortnight of August $\left(\mathrm{D}_{5}\right)$. Other sowing dates occupied middle space. Among cultivars, cv. Bindas $\left(G_{1}\right)$ consistently recorded higher ginning percentage (35.3 on pooled basis); other cultivars were at par with one another and stood next in the order. Among the treatment combinations, irrespective of cultivars early sowing during II fortnight of June $\left(D_{1} G_{1-4}\right)$ had significantly higher ginning percentage; cv. Bindas faring better (38.9 on pooled basis), followed by those sown during I fortnight of July $\left(\mathrm{D}_{2} \mathrm{G}_{1-4}\right)$ and cv Bindas sown during II fortnight of July $\left(D_{3} G_{1}\right)$ which were on par with first sown crop. With further delay in sowing ginning percentage decreased gradually and recorded significantly lower values with last sown crop during II fortnight of August $\left(\mathrm{D}_{5} \mathrm{G}_{1-4}\right)$ when all cultivars fared on par with each other (30.5 to 31.7 on pooled basis).

Lint quality and other quality parameters were superior with early date of sowing irrespective of the genotypes (Table 1-4). In the investigation higher fibre fineness (4.87 on pooled basis), fibre length (37.1 on pooled basis), uniformity ratio (50.6), lint index (8.65 on pooled basis), seed index (10.49 on pooled basis), maturity ratio (10.49 on pooled basis), bundle strength (30.0 on pooled basis) and ginning percentage (38.9 on pooled basis) were obtained with $\mathrm{cv}$. Bindas sown during II fortnight of June $\left(\mathrm{D}_{1} \mathrm{G}_{1}\right)$. Similarly, ElDebaby et al., (1995) and Khalid Usman et $a l$. , (2016) reported higher fibre length with early sowing. The results are also parallel with the findings of Arshad et al., (2007) and Baloch et al., (2001) who reported that late planting reduced fibre strength. Similarly, Elayan et al., (2015) reported higher seed index and stable length with early planting of cotton.

Micronaire indicates an indirect measure of cotton fibre gravimetric fineness (mass per unit length) and is significantly influenced by sowing dates, genotypes and their interactions (Khalid Usman et al., 2016). Deho et al., (2012) reported that micronaire value was lower (more fine fibre) with early sowing in April compared to May sowing having higher micronaire value. While, lowest quality parameters were recorded with late sown crop irrespective of genotypes. Moreover, late sown cotton may reach maturity late in the season and practically farmers harvest immature cotton that contributes to lower fibre strength, nep formation and poor dye uptake (Bradow and Bauer, 1997). Further, fibre uniformity is a measure of the fibre length distribution in a sample. A low uniformity index value indicates that there are shorter fibres ( $<12.7 \mathrm{~mm}$ in length) in a sample than one with a high fibre uniformity for cotton of the same upper half mean length. Similar to present findings, El-Zik et al., (2000) reported that late sowing in the season adversely affected uniformity ratio. Baloch et al., (2001) also communicated analogous results that late sowing of cotton resulted in lower uniformity ratio of cotton. Thus present investigation indicates that fibre uniformity is affected both by sowing date as well as genotypic material; however, the later one seems to have more impact on fibre uniformity. Bednarz et al., (2005) reported that uniformity was a genetically controlled character which could be improved by selection. Seed index is an important component of seed cotton yield and is expressed as the weight of 100 seeds. The 
decrease in the seed index in later sowing dates might be attributed to the poor development of seeds and bolls under delayed sowing conditions due to unfavourable temperature resulting in reduction in boll weight.

\section{References}

Arshad, M., Wajid, A. Maqsood, M. Hussain, K. Aslam M. and Ibrahim, M., 2007, Response of growth, yield and quality of different cotton cultivars to sowing dates. Pak. J. Agri. Sci., 44(2): 208-212.

Baloch, M., S.H. Ghaloo and A.A. Rajper. 2002. Are cotton fiber characters under influence of planting dates? Life Sci. Int. $J ., 1(1): 1-5$.

Bednarz, C.W., Shurley, W.D. and Anthony. W.S., 2005, Yield, quality, and profitability of cotton produced at varying plant densities. Agron. J., 97: 235-240.

Elayan, E. D., Sohair, Abdalla, A. M. A. and Abdel Gawad, 2015, Effect of delaying planting date on yield, fiber and yarn quality properties in some cultivars and promising crosses of Egyptian cotton. American-Eurasian J. Agric. Environ. Sci., 15(5): 754-763.

El-Debaby, A. S, Hammam G. Y, Nagib, M. A., 1995, Effect of planting dates, $\mathrm{N}$ and $\mathrm{P}$ application levels on growth characters of Giza 80 cotton cultivar. Annals Agric. Sci. Moshtohor, 33: 44154.

Khalid Usman, Ayatullah, T., Niamatullah Khan and Sohrab Khan, 2016, Genotype-by-sowing date interaction effects on cotton yield and quality in irrigated condition of Dera ismail khan, Pakistan. Pak. J. Bot., 48(5): 19331944.

\section{How to cite this article:}

Vinayak Hosamani, B.M. Chittapur, Mallikarjun, A.S. Halepyati, Satyanarayana Rao, M.B. Patil, N.L. Rajesh and Venkatesh Hosamani. 2018. Lint Quality as Influenced by of Time of Planting in Bt Cotton (Gossypium hirsutum L.) Cultivars in TBP Irrigation Command. Int.J.Curr.Microbiol.App.Sci. 7(08): 4098-4107. doi: https://doi.org/10.20546/ijcmas.2018.708.426 